\title{
Leininger Theory Development through Mentoring Students and Community-Leaders in Preventing the Spread of COVID-19
}

\author{
Nurul Kamariyah*, Khamida Khamida (D), Siti Nurjanah, Chilyatiz Zahroh(D, Siti Nur HasinaD, Raden Khairiyatul Afiyah \\ Department of Nursing, Faculty of Nursing and Midwifery, Universitas Nahdlatul Ulama Surabaya, Surabaya, East Java, \\ Indonesia
}

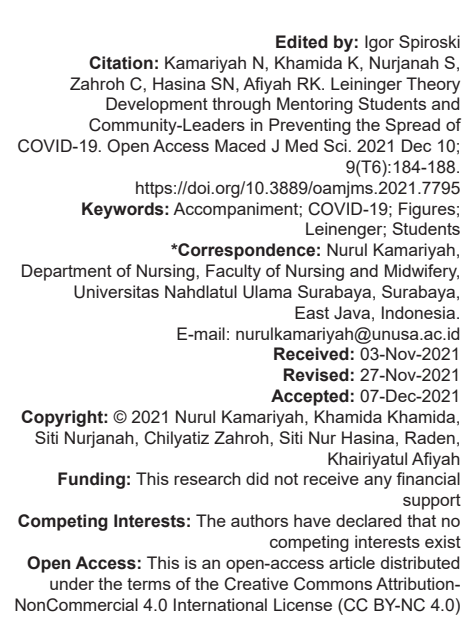

\section{Introduction}

The COVID-19 pandemic requires everyone to behave in a healthy way and prevent the spread of the virus in very simple ways such as wearing masks, keeping a distance, preventing crowds, and washing hands, but most of the people have not behaved optimally to prevent the spread of the virus. The behavior of refusing rapid or swab examinations when there are examinations from officers, and the dishonesty of the public after interacting with COVID19 sufferers. The government's policy with the COVID19 pandemic is that all educational institutions are expected to conduct schools or lectures with an online system (in the network). The policy affects the learning process, mainly through practical and clinical learning that is passed by students, The fear of death is a basic psychological conflict in human [1]. And according to the Terror Management Theory, the fear of an uncertain death makes people do various things to maintain their lives. Every Indonesian citizen who is domiciled as an individual and social being, needs to realize that every decision taken is not only related to himself but also has a relationship with involvement in social life and the surrounding environment. However, the impact of this COVID-19 pandemic is unprecedented. That is when billions of people are forced to isolate at home and there is no certainty about the end of this pandemic, even after social distancing efforts have eased. These include increased levels of anxiety the effects of social isolation. Experts warn that these symptoms are likely to continue constantly in the future [2], [3].

The results of reports in the mass media from the COVID-19 task force in early June 2021 in Bangkalan Madura there was a very significant spike in 25 new cases of positive COVID-19 patients, then 2 COVID-19 patients died and 17 people were declared corona suspects. Based on data from the COVID-19 
Handling Task Force, Sunday (June 6, 2021), there were 1779 cumulative cases of COVID-19 in Bangkalan. A total of 1520 patients were declared recovered, 180 people were declared dead and as many as 79 patients were still undergoing treatment. Results researchers observed in February 2021 that the results of the behavior of the people of Tanjung Madura to wash their hands $2 \%$, wear masks $8 \%$ and keep a distance of $2 \%$, swab $8 \%$, and do not believe in COVID-19 by $90 \%$.

Based on the findings of The Guardian (2020): $28 \%$ experienced post-traumatic stress disorder, $31 \%$ depression, $42 \%$ anxiety or anxiety, 40\% insomnia, and $20 \%$ obsessive-compulsive symptoms paranoia symptoms. The results of the March 2021 survey in the Madura area showed that $8 \%$ of the people wore masks, $8 \%$ were willing to do swabs, $2 \%$ social distancing, $90 \%$ wore masks if there were officers, $100 \%$ washed hands before entering the house, and vaccinated $20 \%$.

The COVID-19 pandemic requires everyone to behave in a healthy way and prevent the spread of the virus in very simple ways such as wearing masks, keeping a distance, preventing crowds, washing hands and there is also a behavior to do a rapid or swab if you want to leave the area, but this behavior is partly. Most people have not behaved optimally to prevent the spread of the virus. The solution that can be done is a community approach with the development of the Leininger model theory carried out by the surrounding community and assistance from students.

The positive impact that can be felt by the community is the government's policies regarding lockdown, social distancing, new normal, and emergency of enforcement of restrictions on community activities. Those have been implemented until now, so that people are more focused on family relationships, health, new activities that are productive and economical such as: The more terms that are known by the public, the more creative people are to use information technology, and increasing literacy.

Meanwhile, viewed from the negative side, some of which are felt by the community which are more felt to date include multidimensional, including: Limited activities, reduced community economic turnover, learning models using online methods that cannot feel face-to-face with teachers or lecturers, causing boredom and boredom. Another negative impact is that the community refuses to comply with the health protocol, lacks discipline, and is dishonest when he interacts with this COVID-19 patient. This will cause stress and anxiety which will result in biological, psychological, social, and spiritual conditions.

Physiologically, when anxious and stressed, it naturally triggers the body's response to react to threats. At that time, the sympathetic nervous system is automatically in self-defense mode. This is controlled by the part of the brain that controls emotions called the amygdala, and then the amygdala sends "distress signals" to the hypothalamus gland at the base of the brain. The hypothalamus then codes for the adrenal glands to release the stress hormones cortisol and adrenaline. Once the hormone is released, the muscles in the body automatically become tense. Muscle tension serves to protect them from injury. The heart also beats faster to pump more blood to the muscles and increase oxygen intake. This is what triggers rapid breathing or shortness of breath and heart palpitations. In a "threatened" state, the body also releases more glucose and fat into the bloodstream to provide additional fuel for a person to be more alert [4].

Sociologically, pandemics cause an organization in society that leads to an uncertain social situation, so that it has an impact on the social order in society. People become over-protective of the surrounding environment, it is easier to be suspicious of people who cough, sneeze, or look pale around our environment in addition to bad views in the form of stigma and discrimination against people with persons under observation, patients under surveillance, suspected COVID-19, patients positive for COVID19, recovered patients, and medical personnel. This stigma eventually gave rise to discriminatory attitudes, for example, refusing to help other people by physical contact with people suspected of having the coronavirus, the refusal of a nurse because the nurse worked in a hospital that received COVID-19 patients, the refusal of burial of the bodies of COVID-19 victims by a number of residents, and the use of shopping apps are on the rise [5].

To prevent the spread of COVID-19 transmission, it is suggested in this study to approach the Leinenger theory with the assistance of students together with community leaders as the impact of the COVID-19 pandemic in East Java will improve the quality of life. The COVID-19 pandemic, which does not yet know when it will end, the public should be able to take advantage of the existing culture according to Leininger's theory, and involve community leaders with health students so that they can increase the level of health of individuals, families, groups, and communities [2], [6].

\section{Methods}

The research design aims to explain the causal relationship between variables. The research population is Madurese people aged 20 years and over who live around the residences of students of the Faculty of Nursing and Midwifery, Nahdlatul Ulama University Surabaya and community leaders as companions who are trusted by the community in providing education and practice in changing people's behavior. The population in this study was 126 . The sampling technique used was total sampling. The instruments used were 
questionnaires and observations. The independent variable is the development of the Leininger theory model (Development of local knowledge and culture), while the dependent variable is the degree of public health. Variables were analyzed descriptively and analyzed using t-test to distinguish before and after mentoring by students and community leaders by developing Leinenger's theoretical model in measuring improving health status. This research is ethical at the Chakra Brahmanda Lentera institution with No. 036/015/VII/ EC/KEP/Lemb.Candle/2021.

\section{Results}

1. The frequency distribution of the Leinenger
model theorydevelopment includes knowledge,
attitudes, and behavior before and after
mentoring students with community leaders to
prevent the spread of COVID-19. Table of the
frequency distribution of the Leinenger model
theory development of respondents before
mentoring students with community leaders to
prevent the spread of COVID-19, Table 1 .

Table 1: Frequency distribution of the Leinenger model theory development of respondents before mentoring students with community leaders to prevent the spread of COVID-19

\begin{tabular}{lll} 
Development & Frequency & Percentage \\
\hline Well & 6 & 5 \\
Pretty good & 13 & 10 \\
Not good & 107 & 85 \\
Total & 126 & 100 \\
\hline
\end{tabular}

Based on the table above shows that of 126 respondents most all (85\%) had poor Leinenger theory development.

2. The frequency distribution of the Leinenger model theory development includes knowledge, attitudes, and behavior before and after mentoring students with community leaders to prevent the spread of COVID-19. Table of the frequency distribution of the Leinenger model theory development for respondents after mentoring students with community leaders to prevent the spread of COVID-19, Table 2.

Table 2: Frequency distribution of the Leinenger model theory development for respondents after mentoring students with community leaders to prevent the spread of COVID-19

\begin{tabular}{lll} 
Development & Frequency & Percentage \\
\hline Well & 72 & 57 \\
Pretty good & 36 & 28 \\
Not good & 18 & 15 \\
Total & 126 & 100 \\
\hline
\end{tabular}

Based on the table above shows that of 126 respondents most (57\%) have good Leinenger theory development.

3. The frequency distribution of the respondent's health levels includes being biologically, psychologically, socially, and spiritually healthy before and after mentoring students with community leaders to prevent the spread of COVID-19. The frequency distribution table of the respondent's health is disturbed before mentoring students with community leaders to prevent the spread of COVID-19, Table 3.

Table 3: Frequency distribution of the respondent's health is disturbed before mentoring students with community leaders to prevent the spread of COVID-19

\begin{tabular}{lll} 
Health degree & Frequency & Percentage \\
\hline Not disturbed & 27 & 21 \\
Disturbed & 99 & 79 \\
Amount & 126 & 100 \\
\hline
\end{tabular}

Based on the table above, it shows that from 126 respondents before mentoring students with community leaders almost all $(79 \%)$ were disturbed.

4. The frequency distribution of the respondents' health levels includes being biologically, psychologically, socially, and spiritually healthy after mentoring students with community leaders to prevent the spread of COVID-19. Table of frequency distribution of respondents' health degrees after mentoring students with community leaders to prevent the spread of COVID-19, Table 4.

Table 4: Frequency distribution of respondents' health degrees after mentoring students with community leaders to prevent the spread of COVID-19

\begin{tabular}{lll} 
Health degree & Frequency & Percentage \\
\hline Not disturbed & 19 & 15 \\
Disturbed & 107 & 85 \\
Amount & 126 & 100 \\
\hline Source: Primary data, July 2021. & &
\end{tabular}

Based on the table above, it shows that from 126 respondents after mentoring students with community leaders almost all (85\%) were impaired.

5. Cross tabulation of the Leinenger model theory development with the respondent's health status before mentoring students with community leaders to prevent the spread of COVID-19. Table of cross tabulation of Leinenger model theory development with health degrees before mentoring students with community leaders to prevent the spread of COVID-19, Table 5.

Table 5: Cross tabulation of Leinenger model theory development with health degrees before mentoring students with community leaders to prevent the spread of COVID-19

\begin{tabular}{|c|c|c|c|c|c|c|}
\hline \multirow[t]{3}{*}{ Development } & \multicolumn{4}{|c|}{ Health degree } & \multirow[t]{3}{*}{ Total } & \multirow[t]{3}{*}{ Percentage } \\
\hline & \multicolumn{2}{|c|}{ Not disturbed } & \multicolumn{2}{|c|}{ Disturbed } & & \\
\hline & $\mathrm{n}$ & $\%$ & $n$ & $\%$ & & \\
\hline Well & 4 & 67 & 2 & 33 & 6 & 100 \\
\hline Pretty good & 7 & 54 & 5 & 46 & 13 & 100 \\
\hline Not good & 15 & 14 & 92 & 86 & 107 & 100 \\
\hline Total & 27 & 21 & 99 & 79 & 126 & 100 \\
\hline
\end{tabular}

Based on the table above, it shows that of the 107 respondents who had poor development of the Leinenger theory model, almost all (86\%) had a degree of impaired health.

6. Cross tabulation of the Leinenger model theory development with the respondent's health level after mentoring students with community 
leaders to prevent the spread of COVID-19. Table of cross tabulation on the development of the Leinenger model theory with the degree of health after mentoring students with community leaders to prevent the spread of COVID-19, Table 6.

Table 6: Cross tabulation on the development of the Leinenger model theory with the degree of health after mentoring students with community leaders to prevent the spread of COVID-19

\begin{tabular}{|c|c|c|c|c|c|c|}
\hline \multirow{3}{*}{ Development } & \multicolumn{4}{|c|}{ Health degree } & \multirow{3}{*}{ Total } & \multirow[t]{3}{*}{$\%$} \\
\hline & \multicolumn{2}{|c|}{ Not disturbed } & \multicolumn{2}{|c|}{ Disturbed } & & \\
\hline & $\mathrm{n}$ & $\%$ & $\mathrm{n}$ & $\%$ & & \\
\hline Well & 62 & 86 & 10 & 14 & 72 & 100 \\
\hline Pretty good & 30 & 83 & 5 & 17 & 36 & 100 \\
\hline Not good & 12 & 67 & 6 & 33 & 18 & 100 \\
\hline Total & 19 & 15 & 107 & 85 & 126 & 100 \\
\hline
\end{tabular}

Based on the table above, it shows that of the 72 respondents who have a good Leinenger theory model development, almost all (86\%) have an undisturbed level of health.

The results of the cross tabulation of differences before and after mentoring students with community leaders between the development of the Leinenger theory and the degree of public health impact of the COVID-19 pandemic were obtained from the results of the analysis using the t-test test using Statistical Package for the Social Sciences for windows with a level of $=0.05$, the value of $=$ 0.00 which means then there are differences in the development of Leinenger theory before and after mentoring students with community leaders with the degree of public health including biological, psychological, social, and spiritual needs as a result of the COVID-19 pandemic.

\section{Discussion}

The development of the Leininger model theory with the degree of health before mentoring students with community leaders

Based on the results of research from 107 respondents who had poor development of the Leinenger theory model, almost all (86\%) had a degree of impaired health. The development of the Leinenger model pays great attention to the development of science and culture that is believed by the community, so that is the target in providing education to the community. Before mentoring with students he got poor results due to this COVID-19 pandemic, suddenly this pandemic happened which made people not ready to face it, surprised, and not able to adapt. People become angry, protest, stressed, because they cannot work optimally, they can't earn income so that their biological, psychological, and spiritual needs are disturbed. It is proven that the results of research before mentoring, most of the community did not empower existing science and culture to adapt to the COVID-19 pandemic conditions, supported by the frequency distribution of gender, almost all of whom were women. Women in analyzing situations and conditions that are not prepared become irritable and more difficult to adapt, because women have limited analysis, are less able to develop their thinking power, are less able to think clearly. Therefore, the concept of Leinenger theory with the development of science and culture around the respondent must be empowered that does not conflict with health such as the use of mask materials, plants to increase endurance, running water for washing hands, which are available in the surrounding environment, and providing education to prevent the spread of the COVID-19 virus must be with influential people in the surrounding environment such as clerics or community leaders. I am prepared and able to adapt to the situation and conditions of this COVID-19 pandemic which does not know when it will end. This is supported by Leininger's theory, namely, the application of a nursing care provided to individuals according to cultural backgrounds. The strategies used in providing nursing care according to Leininger include: (1) Maintaining culture is carried out if the culture adopted by the individual does not conflict with health. Nursing planning and implementation are given according to relevant values so that individuals can improve or maintain their health status. For example, the culture of drinking water every time you wake up. (2) Negotiating or accommodating culture negotiations are carried out to help individuals adapt to certain cultures that are more beneficial to health. Nurses help individuals to be able to choose and determine other cultures that are more supportive of improving health, for example, after surgery, patients who abstain from eating fishy-smelling foods can be replaced by eating other animal protein sources such as egg whites. (3) Changing or changing individual culture changing or restructuring the culture is carried out if the culture adopted is detrimental to health. Nurses try to restructure patients' lifestyles that are not good to be good such as smoking culture [7], [8].

\section{The development of the Leininger model} theory with the degree of health after mentoring students with community leaders

Based on the results of the study showed that of the 72 respondents who had a good Leinenger theory model development, almost all (86\%) had an undisturbed level of health.

Assistance from competent people and people who are trusted by the community such as scholars or community leaders will greatly affect the development of existing knowledge and culture related to preventing the spread of the COVID-19 virus. Assistance carried out with students of the Faculty of Nursing and Midwifery to the community around the place Students living together with community leaders make it easy for students to communicate, interact and provide 
education, supported by the situation and conditions during this COVID-19 pandemic. Students who are competent in their fields of health, especially nursing students, will be better able to provide knowledge and be able to empower respondents' local knowledge and culture according to Leinenger's theory, by utilizing and empowering the culture and beliefs of the respondent so that it does not interfere with the mindset and behavior that does not conflict with health. Supporting data, all students are willing to involve themselves as assistants in the surrounding community and most of the students are female as community companions to prevent the spread of COVID-19 [9].

Caring is direct action directed at guiding, supporting and directing individuals, families, groups in real situations or anticipated needs to improve human living conditions. Cognitive abilities that can be used to determine belief values and expression patterns aim to support and provide individual opportunities, guide families or groups. The goal is that individuals or groups can maintain health, be healthy, thrive, survive, and live in limitations until death in peace. Principles of Transcultural Nursing Care consist of culture/culture is the rules that are carried out from members of the studied group, and provide goals by way of thinking, acting and making decisions, cultural value is the individual's willingness to take a more desirable action or action that is always maintained, cultural differences in nursing are the optimal form of providing nursing care and refer to cultural care and respect the cultural values of others. This principle can be implemented in Islamic boarding schools with different origins of students [2], [10], [11].

\section{Cross tabulation of differences before and after mentoring students with community leaders between the development of the Leinenger theory and the degree of public health impact of the COVID-19 pandemic}

There are differences in the development of Leinenger theory before and after mentoring students with community leaders with degrees of public health including biological, psychological, social, and spiritual needs as a result of the COVID-19 pandemic. By assisting nursing students with community leaders or people trusted by the community to provide knowledge, and their behavior to the surrounding community, it will be easier for the community to imitate or take their knowledge as important information in changing their behavior. With competent knowledge and the closeness of students to the community because it is an area that is already known to students so that students will find it easier to develop and empower their experiences to invite the community in accordance with government policies with rules regarding health protocols [12], [13], [14].

\section{Conclusion}

There are differences in knowledge, attitudes, behavior and degrees of public health before and after mentoring students with community leaders to prevent the spread of COVID-19.

\section{References}

1. Inter-Agency Standing Committee. Catatan Tentang Aspek Kesehatan Jiwa dan Psikososial Wabah COVID-19 Versi 1.0 2020. Available from: https://www.who.int/docs/default-source/ searo/indonesia/covid19/catatan-tentang-aspek-kesehatanjiwa-dan-psikososial-wabah-covid-19-feb-2020-indonesian. pdf?sfvrsn=ebae5645_2 [Last accessed on 2021 Oct 22].

2. Machado DB, Alves FJ, Teixeira CS, Rocha AS, Castro-de-Araujo LF, Singh A, et al. Effects of COVID-19 on Anxiety, Depression and Other Mental Health Issues: A Worldwide Scope Review. Research Square; 2020. http://doi.org/10.21203/rs.3.rs-58186/v1.

3. Jarnawi. Mengelola Cemas Di Tengah Pandemik Corona. Jurnal At-Taujih Bimbingan dan Konseling Islam Vol. 3 No. 1 JanuariJuni; 2020. Available from: http://jurnal.ar-raniry.ac.id/index.php/ Taujih. http://doi.org/10.22373/taujih.v3i1.7216

4. Nemec R, Carmicheal C. Application of Leininger's theory of transculturalnursingintopractice. Hemodialysis Int.2004;8(1):109. https://doi.org/10.1111/j.1492-7535.2004.0085cc.x

5. Burhan E, Isbaniah F, Susanto AD. Pneumonia Covid-19 Diagnosis and Penatalaksanaan Di Indonesia. Jakarta: Perhimpunan Dokter Paru Indonesia; 2020.

6. Shereen MA, Khan S, Kazmi A, Bashir N, Siddique B. COVID19 infection: Origin, transmission, and characteristics of human coronaviruses. J Adv Res. 2020;24:91-8.

7. Damawiyah S, Soleha U, Umamah F. Hubungan Efikasi Diri Dan Motivasi Mencegah Komplikasi Dengan Derajat Hipertensi (covid 19)Pada Lansia Di Rw 01 Kelurahan Wonokromo Surabaya. Surabaya: Fakultas Keperawatan Dan Kebidanan Unusa; 2017.

8. Daniel J. Education and the COVID-19 pandemic. Prospects. 2020;49(1):91-6.

9. Hasanah L, Sumarni S, Mulyadi E. Assistance in preventing the spread of COVID-19 in Errabu village, Bluto district, Sumenep regency. J Abdimas Bina Bangsa. 2020;1(1):71-7. https://doi. org/10.46306/jabb.v1i1.11

10. Fatwikiningsih N. Teori Psikologi: Kepribadian Manusia. $1^{\text {st }}$ ed. Yogyakarta: Andi; 2020.

11. Yumnah S. Assistance in the community health empowerment program against COVID-19 through the pomegranate posyandu cadre community in Glanggang village. Abdi Kami J Pengabdian Kepada Masyarakat. 2021;4(1):37-47. https://doi.org/10.29062/ abdi_kami.v4i1.443

12. Fitria L. Cognitive Behavior Therapy Counseling Untuk Mengatasi Anxiety Dalam Masa Pandemi Covid-19. Vol. 10. ALIRSYAD; 2020.

13. Setyaningrum $W$, Yanuarti HA. The influence of COVID-19 on the mental health of the people in Malang city. J IImu Sos Pendidikan. 2020;4(4):1580. http://doi.org/10.36312/jisip.v4i4.1580

14. Raony I, de Figueiredo CS, Pandolfo P, Giestal-de-Araujo E, Oliviera-Silva Bomfim P, Savino W. Psycho-neuroendocrine immune interactions in COVID-19: Potential impacts on mental health. Front Immunol. 2020;11:1170. http://doi.org/10.3389/fimmu.2020.01170 PMid:32574266 